\title{
DEVELOPING A TECHNOLOGY-BASED BUSINESS STRATEGY FOR THE INTERNATIONAL BUSINESS OF TELKOM SA
}

\author{
M. John ${ }^{1}$ and A.J. Buys ${ }^{2}$ \\ ${ }^{2}$ Department of Engineering and Technology Management \\ University of Pretoria, South Africa \\ johnm@telkom.co.za, ajbuys@up.ac.za
}

\begin{abstract}
This study was aimed at developing a technology-based business strategy for Telkom's international business. Deregulation, competition and demand for converging voice, data and video in the telecommunication market were the driving forces behind this study. Without a proper strategy, Telkom will not be able to withstand the new competition. As the initial step in strategy formulation, Telkom's strategic goals were identified. A SWOT analysis was conducted and a strategy formulation map was developed. A technology balance sheet and Scurve models were developed to analyse the current products and technologies. It become evident through the research that there is a high potential for business expansion into Africa and Telkom has sufficient capabilities to support this. The implementation of voice over Internet protocol technology will enable Telkom to deliver international services at competitive rates. The study concluded by developing a technology strategy for Telkom's international business. Recommendations are put forward and future research gaps are identified.
\end{abstract}

\section{OPSOMMING}

Die doel van hierdie studie was om 'n tegnologie-gebaseerde besigheidstrategie vir Telkom se internasionale besigheid te ontwikkel. Deregulering, mededinging en die vraag na konvergensie van stem, data en video in die telekommunikasiemark was die dryfkragte agter hierdie studie. Sonder ' $\mathrm{n}$ behoorlike strategie sal Telkom nie teen die nuwe mededinging kan staande bly nie. As eerste stap in die formulering van ' $n$ strategie, is Telkom se doelwitte geïdentifiseer. ' $n$ SWOT-analise is uitgevoer en 'n strategieformuleringskaart is ontwikkel. ' $n$ Tegnologiebalansstaat en S-krommemodelle is ontwikkel om die bestaande produkte en tegnologieë te ontleed. Hierdie navorsing het aangetoon dat daar ' $n$ hoë potensiaal vir uitbreiding van Telkom se besigheid in Afrika bestaan en dat Telkom genoegsame vermoëns besit om dit te ondersteun. Die implementering van 'voice over Internet protocol'-(stem oor die Internet)tegnologie sal Telkom in staat stel om ' $n$ internasionale diens teen ' $n$ mededingende prys te lewer. Die studie is afgesluit met die ontwikkeling van " $n$ tegnologiestrategie vir Telkom se internasionale besigheid. Aanbevelings word gedoen en velde vir verdere navorsing is geïdentifiseer.

\footnotetext{
${ }^{1}$ The author was enrolled for the M Eng (Engineering Management) at the Department of Engineering and Technology Management, University of Pretoria
} 


\section{INTRODUCTION AND BACKGROUND}

The current global trend in the telecommunication industry indicates that there is an increasing demand in data traffic, where voice was the previous leading traffic. This is due to the rapid expansion of data networks on the Internet. This results in an increasing demand for the integration of voice, data and video on the same network. As the telecommunication market is being liberalised, it is expected that many competitors (both nationally and internationally) will compete with Telkom in the international market. If it has no proper technology-based business strategy, Telkom will not be able to survive and grow in the new competitive environment, as many of its current technologies may soon become obsolete. For these reasons, the necessity of developing a technology-based business strategy for the organisation is crucial.

\section{Organisational Background}

Telkom is a telecommunication service provider, providing integrated voice and data services through its land line and wireless networks into Africa and other countries. Telkom also provides cellular communication services through Vodacom, of which Telkom holds $50 \%$ of the shares. Telkom's shareholders are the South African Government, Southwestern Bell Company (SBC) USA and Telekom Malaysia. The South African government is the major shareholder with 70 per cent of the shares, and the two international telecommunication companies, namely SBC and Telekom Malaysia, share the remaining 30 per cent of the shareholding.

\section{Telkom Infrastructure}

International telecommunication services are provided through terrestrial and satellite networks. International communication mainly comprises data and voice. Telkom has direct access to the neighbouring countries via the terrestrial links and access to other countries is established via satellite and/or submarine cable links. An international trunking exchange (ITE) is located in Johannesburg and serves as the gateway for incoming and outgoing international calls. There are in fact two ITEs to handle the international traffic load.

\section{Current technologies used in the International Network}

Currently, many technologies are used in the international network. These are X.25, frame relay, Asynchronous transmission mode, diginet, synchronous data hierarchy, wavelength division multiplexing, Internet protocol, asynchronous digital subscriber line, single carrier per channel, time division multiple access, demand assigned multiple access, intermediate data rate and frequency division multiple access.

\section{RESEARCH PROBLEM AND OBJECTIVES}

The deregulation of the telecommunication industry in South Africa opened the way for new operators to enter into the telecommunication market. This has forced Telkom into a new competitive market, where Telkom was the only operator up to May 2002. With its past monopoly status, Telkom did not gain any exposure to competition. 
Another threat that Telkom faces is Internet telephony. Currently, many international calls are bypassing the public switched telecommunication network (PSTN) and are routed via the Internet. Internet telephony is made possible by voice over Internet protocol (VoIP). Growth in the VoIP market is expected to be considerable over the next five years. Estimations by Radcom [1] put the global annual growth rate for IP-enabled telephone equipment at 132 per cent between 1997 and 2002 with an expected market of some US\$ 3.16B in 2002. Lightfoot, Bertoldi \& Heydenrych [2] for BMI-TechKnowledge predict that by 2005, the Internet usage in South Africa will have increased by 35 per cent from the current level. Internet telephony is currently a loss of income to Telkom. Telkom needs to develop a strategy to counter this threat.

The research objective was to develop a technology-based business strategy for the international business of Telkom SA in a deregulated market by applying strategy formulation methodologies.

\section{THEORETICAL FRAMEWORK}

The theories applied in the research are discussed briefly in the following sections.

\section{Strategic Management Model}

A strategic management model described by Pearce \& Robinson [3] was adopted and used for this study. The initial activity in this model is to define the company's mission and its social responsibilities. The mission of a company distinguishes its unique purpose from those of other companies of the same nature. Once the mission is defined, the company's external environment is analysed to determine its opportunities, threats and constraints. Concurrently, an internal analysis needs to be conducted in order to determine the company's tangible, intangible and organisational capabilities. The internal and external analyses form a critical base for strategy formulation. The strengths, weaknesses, opportunities and threats identified through internal and external analyses are evaluated against the company's mission to determine the company's long-term and grand strategies.

Long-term objectives provide specific benchmarks for evaluating the organisation's progress with achieving its goals. These long-term objectives are measurable over time. The grand strategies provide a comprehensive approach to guiding major actions designed to accomplish the long-term objectives. Grand strategies should be translated into routine activities of key functional areas (functional tactics) for the successful implementation of the strategies. The successful implementation of strategies depends on the efficiency and effectiveness of getting the work done. Restructuring, re-engineering and refocusing might be required for a competitive position in the global market. In order to detect any problems or changes in the strategy implementation, a continuous improvement process is necessary. It helps to determine the company's performance and the direction in which the business is heading. Strategic control deals with tracking a strategy to detect its problems during its implementation and making the necessary adjustments.

\section{Technology Balance Sheet and S-curve Model}

A technology-product framework can be used to identify and prioritise the leading 
technologies and products related to the market situation for a competitive position. A Technology Balance Sheet suggested by De Wet [4] can be used to develop a technologyproduct framework. According to Lindsay [5], the technological capabilities of the organisation must be ranked and assessed according to the technological maturity of its products under consideration. The S-curve model proposed by Nieto, Lopez \& Cruz [6] helps to analyse the maturity of the organisation's products and technologies.

\section{RESEARCH METHODOLOGY}

This section discusses the research design and methodology followed in the study.

\section{Strategy Development Process}

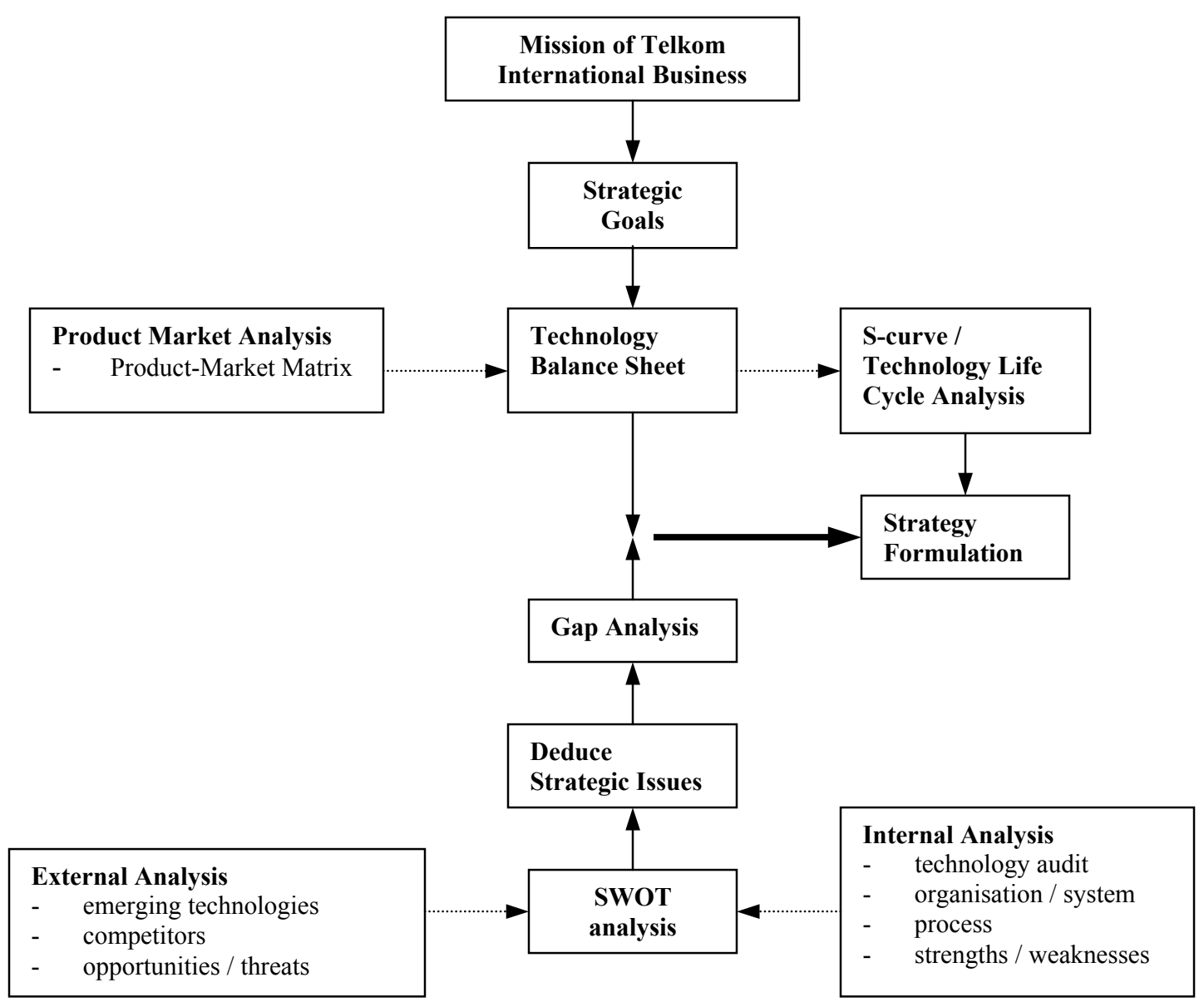

Figure 1: Strategy Development Process

As shown in figure 1, the strategy development process began by analysing the mission and vision of Telkom. Analysing the mission and vision helps to identify the strategic goals that form the foundation for the strategic planning process. After the identification of goals, Telkom's internal strengths and weaknesses were studied in order to recognise the key capabilities, constraints, aspirations, resources and constituencies of the organisation. Concurrently, the external environment was scanned to understand customers, markets, 
competitors and suppliers and thus deducing the strategic issues. Gap analysis could then be used to identify the current capabilities and deficiencies of Telkom with respect to the competitors in the same market.

A technology-product matrix was developed to provide an indication of the current technologies and their priorities. The technology-product matrix was then used in the technology balance sheet for analysing/comparing the proposed technology with that of the current ones. The technology balance sheet indicates the technologies that will support Telkom's international business in the long run. The technology-based business strategy was formulated from the results obtained from the SWOT analysis, technology balance sheet and the S-curve model.

\section{Research Instruments}

Data collection for the SWOT analysis was done by means of a questionnaire, covering various aspects of the internal and external environment. For the development of the technology balance sheet, data were collected from sources such as Telkom internal information, the Internet, technology comparison sheets from various suppliers, product catalogues and from previous surveys of technologies and services.

\section{STRATEGY FORMULATION}

The four major forces that challenge Telkom are competitors, customers, technology and regulations. In order to evaluate Telkom's position in the midst of these challenging forces, a SWOT analysis was conducted to determine the capabilities of the organisation to attain its goals successfully. The strengths identified are listed as S1, S2, etc, weaknesses as W1, W2, etc, the opportunities as $\mathrm{O} 1, \mathrm{O} 2$, etc and the threats as T1, T2, etc. A summary of the SWOT analysis is shown in Table 1.

The SWOT analysis was followed by the development of a technology balance sheet. As the initial step in the development of the technology balance sheet, a product-market matrix, technology-product matrix and value chain were developed. The product-market matrix was used to identify the leading products in the market. The technology-product matrix indicates the different services and the relevant technologies applicable to each service. The value chain was developed to identify the processes or activities that form the building blocks of competitive advantage. The processes identified by means of the value chain were used to create the technology balance sheet. The technology balance sheet is shown in Table 2 .

The performances of different technologies were compared by means of the S-curve model, shown in figure 2. The figure indicates the maximum information rate attained over a period, for different technologies considered in this research. The optic fibre, IP and satellite technologies in particular are still in the growth stage.

Using the identified strengths, weaknesses, opportunities and threats, a strategy formulation map was created to develop offensive, defensive, developmental and avoidance strategic options. These are indicated in table 3. 


\section{STRENGTHS}

S1. Solid telecommunication infrastructure.

S2. Joint partnership programme with the leading telecommunication and information technology companies. S3. Sufficient capabilities and resources for business expansion into Africa. Highly qualified expertise in telecommunication and IT fields.

S4. Sound financial background for business expansions.

S5. Very experienced strategic partners.

S6. Good relationship with international operators.

S7. Maintaining the telecommunication standards set by the local and international standards organisations.

S8. Not hesitant to adopt new technologies.

S9. Efficient billing system in place.

S10. Competitive mind-set programme in place to tune the mind of the employees.

\section{OPPORTUNITIES}

O1. Other African countries lack telecommunication infrastructure.

O2. Demand for a better international call rate in Africa as a whole.

O3. Leading political role of South Africa on the African continent and in the SADC region.

O4. Increasing demand for voice connectivity in many

African countries.

O5. Steady growth of the international call traffic.

O6. Global trend towards deregulation and privatisation of the telecommunication industry.

O7. Low teledensity on the African continent.

O8. Established relationships with international telecom operators.

O9. Global trend in the convergence of telecommunication and information industries.

O10. Demand for voice and data integrated services.

O11. Demand for end-to-end managed service in the corporate environment.

O12. Increasing number of Internet users and ISPs.

O13. Ever-increasing bandwidth demand for data.

O14. Business expansion opportunities from the Nepad.

\section{WEAKNESSES}

W1. No point of presence in any other country. W2. Inadequate technical exposure to emerging technologies.

W3. In-house R \& D initiatives insufficient. W4. Inefficient lines per employee ratio.

W5. Uneven workforce distribution in core business areas.

W6. Current management structure, style and red tape.

W7. No previous experience as a competitor in the international market.

W8. Competitors have established their presence in other African countries.

W9. Maintaining legacy networks.

W10. Lack of knowledgeable suppliers.

W11. Technical and marketing skills are not fully developed to compete in the international market.

\section{THREATS}

T1. Deregulation of international

telecommunication services and legal usage of

VoIP in South Africa by VANS and other network operators.

T2. PC to phone and PC-to-PC international calls via Internet, bypassing Telkom network.

T3. Infrastructure sharing with the SNO.

T4. Competitors are well-known role players in the international market.

T5. Competitors with good financial backing could establish their business at a faster pace.

T6. Inconsistent workforce distribution within Telkom.

T7. The past mentality of being a sole telecommunication operator in South Africa is still prevalent in the minds of many Telkom employees.

T8. Brain drain in South Africa.

T9. Political instabilities on the continent, social issues such as the Aids epidemic, crime, natural disasters such as floods and storms could jeopardise the business expansion initiatives. T10. Regulatory constraints in certain countries do not allow entering into these markets.

T11. Managing staff numbers through retrenchments might affect the highly skilled workforce.

T12. Maintaining the legacy networks.

T13. Lack of knowledgeable suppliers.

T14. Inflation rate indirectly increases the service charges.

T15. The private telecommunication networks in South Africa cause loss of income for Telkom business. 
TECHNOLOGIES

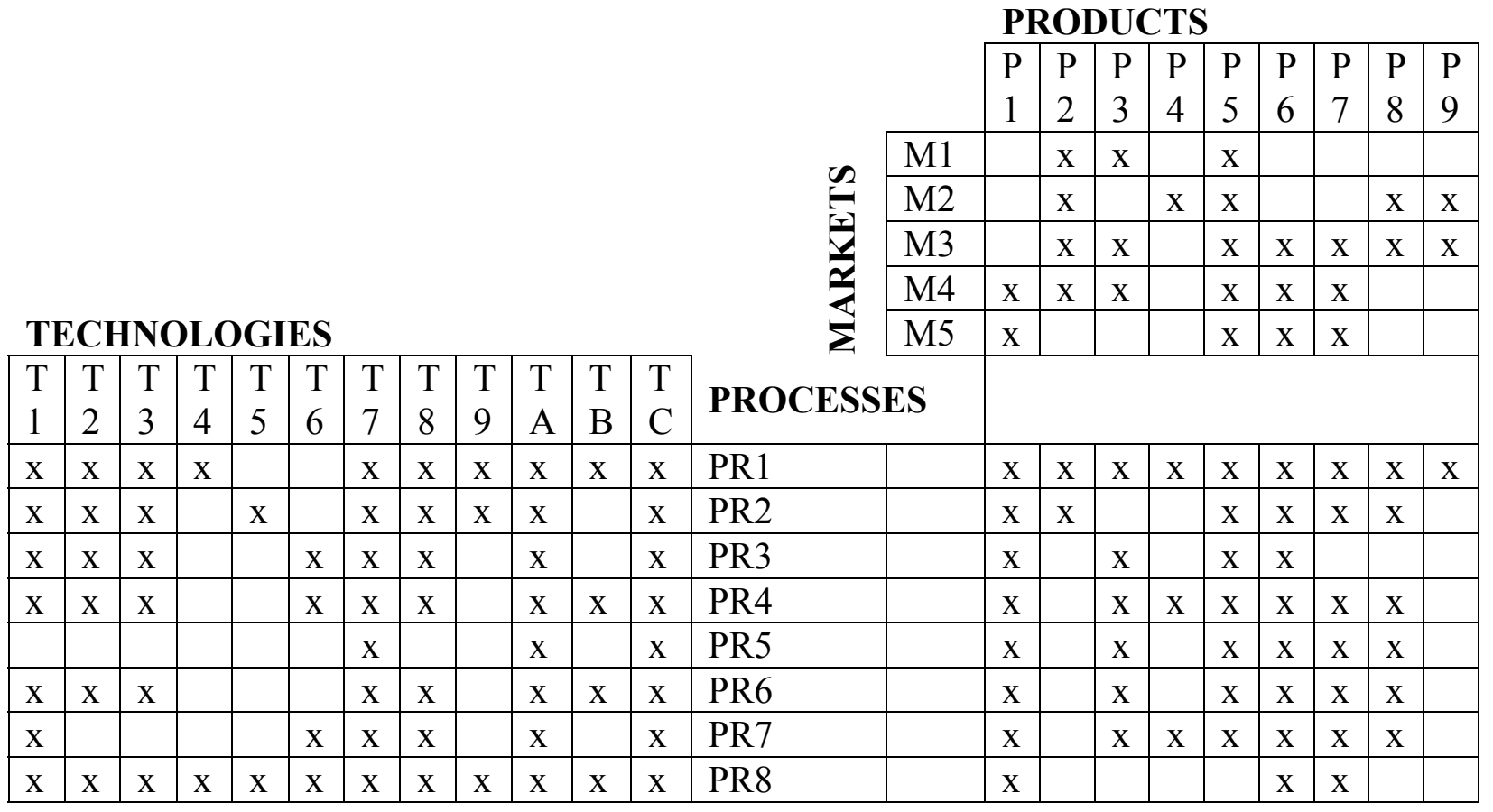

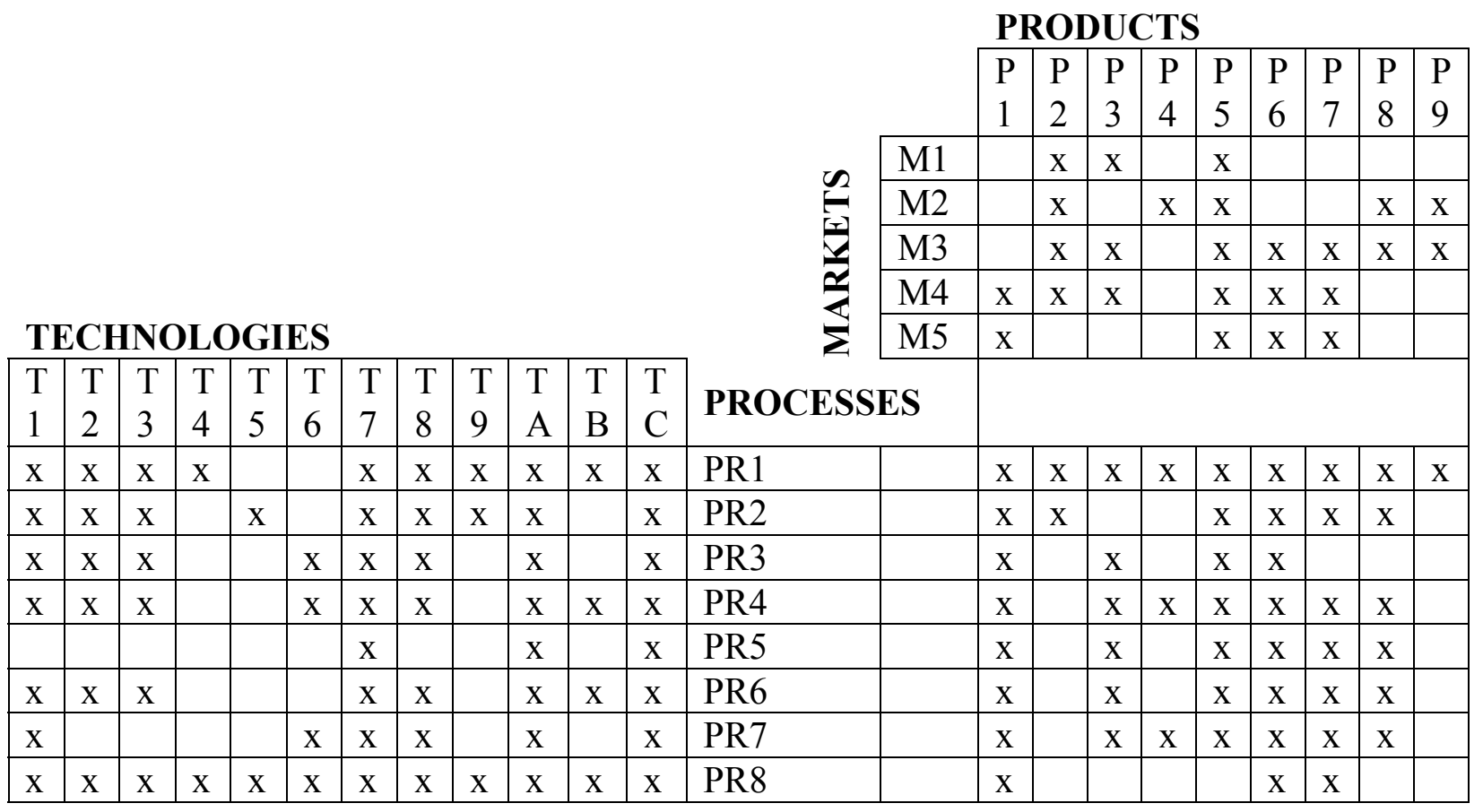

Table 2: Technology Balance Sheet

\begin{tabular}{|l|l|l|l|}
\hline PRODUCTS / & MARKET & TECHNOLOGIES & PROCESS \\
SERVICES & & & \\
\hline P1 - Broadcasting & M1 - Residential & T1 - ATM & PR1 - Technology integration \\
P3 - Infonet & M2 - Commuter & T2 - ADSL & PR2 - Network planning and \\
P4 - Inmarsat & M3 - Business & T3 - ISDN & design \\
P5 - International voice & M4 - Corporate & T4 - Intelligent Network & PR3 - Service integration \\
service & M5 - International & T5 - PSTN & PR4 - Network management \\
P6- IPLC & Telco operators & T7 - Ethernet (IP) & PR5 - Remote management \\
P7 - IVSAT & & T8 - SDH & Quality of service \\
P8 - Maritime services & & T9 - Wireless & PR7 - Disaster Recovery \\
P9- WorldCall & & TA - Satellite & PR8 - Network Surveillance \\
& & TB - X.25 & \\
& & TC - VoIP & \\
\hline
\end{tabular}

\section{Codes used in Technology Balance Sheet}

The offensive strategic options were developed through the combination of opportunities and strengths and are listed as OS1, OS2, etc. Defensive strategic options were developed by combining threats and strengths and are listed as TS1, TS2, etc. Developmental strategic options were developed by combining opportunities and weaknesses and are listed as OW1, OW2, etc. Avoidance strategic options were developed by combining threats and weaknesses and are listed as TW1, TW2. The appropriate combinations of strengths, weaknesses, opportunities and threats are indicated in brackets after each strategic option. 


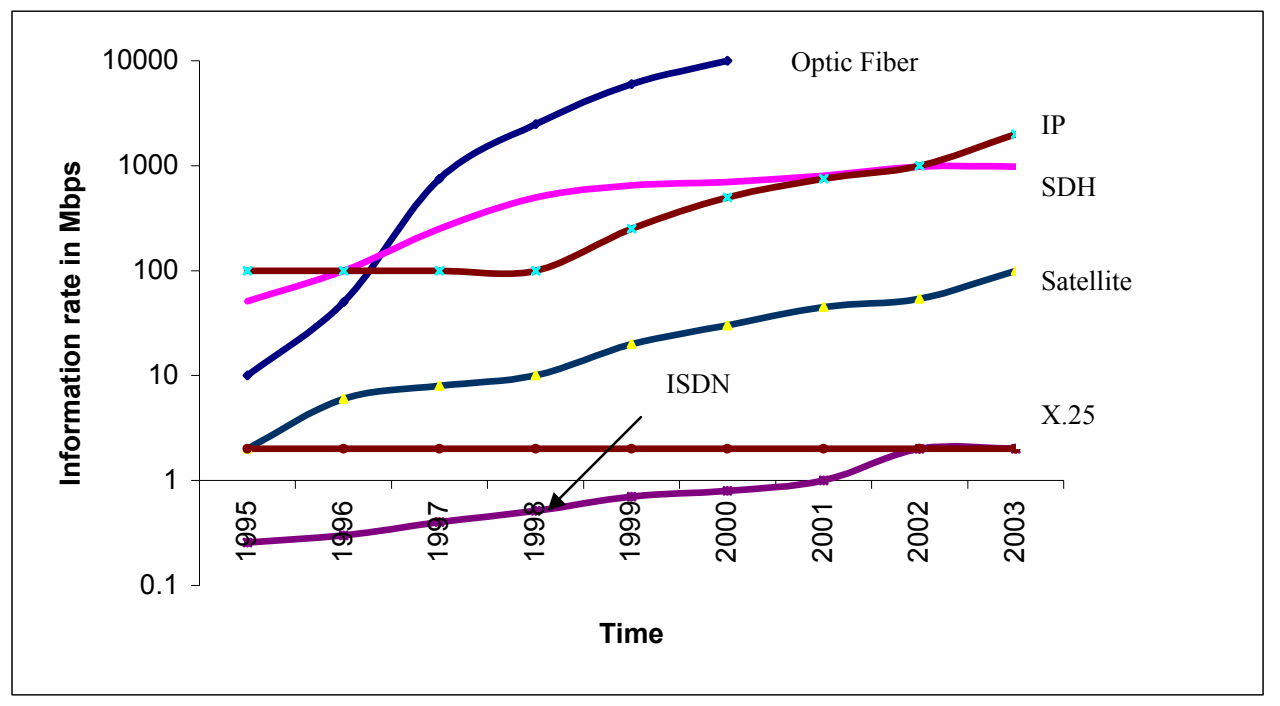

Figure 2: S-curves indicating the performance of different technologies

\section{OFFENSIVE \\ OS1. Aggregate international calls from African countries. (S1, S3, S6, S9 + O1, O2, O4, O5, O8, O13)}

OS2. Act as a bandwidth wholesaler for the African continent. (S1, S2, S6, S7, S9 + O1, O2, O3, O4, O5, O8, O10, O12, O13, O14)

OS3. Offer satellite services in those countries that lack terrestrial infrastructure. (S1, S2, S3, S9 + O1, O4, O5, O8, O9, O10, O12, O13)

OS4. Expand the Vodacom network into Central or East African countries. (S3, S5, S8, S9 + O1, O4, O5, O13, O14)

OS5. Use the existing marketing and sales workforce to explore potential markets in Africa and rapidly roll out satellite networks to capture the market. (S1, S3, S4 + O1, O2, O4, O5, O10, O11, O13)

OS6. Introduce VoIP technology for bandwidth efficiency. (S1, S2, S3, S8 + O2, O4, O5, O10, $\mathrm{O} 12, \mathrm{O} 13, \mathrm{O} 14)$

OS7. Purchase additional satellite bandwidth capacity that can offer Internet traffic for Africa.

\section{DEVELOPMENTAL}

OW1. Identify a country with a high potential for infrastructure development and establish a regional sales and marketing office. Obtain guidance for business expansion through strategic partnerships. Expand into other countries as a service provider. $(\mathrm{O} 1, \mathrm{O} 2, \mathrm{O} 4$, O5, O7, O8, O13, O14 + W1, W7, W8)

OW2. Allocate more funds and create initiatives for in-house research and development. Focus in-house $R \& D$ on emerging technologies. (O9, O10, O11, O12, $\mathrm{O} 13+\mathrm{W} 2, \mathrm{~W} 3, \mathrm{~W} 10)$

OW3. Telkom must bring its lines-peremployee ratio on par with other leading world-class international operators. (W4)

OW4. Evenly distribute the skilled workforce in the core business areas. $(\mathrm{O} 2, \mathrm{O} 4, \mathrm{O} 5, \mathrm{O} 10+$ W5)

OW5. Current hierarchical structure does not contribute to gaining competitive advantage. Cross-functional structures should be developed. (O1, O11, O14 + W6)

OW6. Utilise the competitive mind-set 


\begin{tabular}{|c|c|}
\hline $\begin{array}{l}\text { (S2, S4, S5 + O1, O9, O12, O13, O14) } \\
\text { OS8. Introduce new satellite-based multimedia } \\
\text { network platforms with future expansion } \\
\text { capabilities from leading vendors. (S3, S4, S5, } \\
\text { S6, S8, S9 + O1, O9, O10, O11, O12, O13, O14) }\end{array}$ & $\begin{array}{l}\text { Programme to change fearful minds to } \\
\text { challenging minds. (O3, O6, O14 + W7, W8) } \\
\text { OW7. Gradually phase out the legacy } \\
\text { networks by migrating the customers to the } \\
\text { emerging networks. (O1, O4, O5, O7, O13 + } \\
\text { W9) } \\
\text { OW8. Make use of knowledge transfer from } \\
\text { suppliers to improve the skills of employees. } \\
\text { (O10, O11, O12, O13, O14 + W2, W3, W10, } \\
\text { W11) } \\
\text { OW9. Take initiatives to improve the sales, } \\
\text { marketing and technical skills of employees. } \\
\text { (O2, O4, O5, O6, O7, O11, O12, O13, O14 + } \\
\text { W1, W2, W7, W10, W11) } \\
\text { OW10. Expand the satellite network to } \\
\text { provide VoIP services to countries with a } \\
\text { demand for VoIP solution. (O1, O2, O5, O7, } \\
\text { O9, O10, O12, O13 + W3, W7, W11) }\end{array}$ \\
\hline DEFENSIVE & AVOIDANCE \\
\hline $\begin{array}{l}\text { TS1. Telkom can offer international services at } \\
\text { competitive rates, using VoIP. (T1, T2, T5, T15 + } \\
\text { S1, S2, S4, S8, S9) } \\
\text { TS2. Utilise excess bandwidth capacity to capture } \\
\text { the international market. (T3, T12, T15 + S1, S3, } \\
\text { S5, S6) } \\
\text { TS3. Establish points of presence in other } \\
\text { countries by opening regional offices. (T4, T6 + } \\
\text { S1, S2, S3, S4) } \\
\text { TS4. Implement new restructuring and staff- } \\
\text { retention strategies. (T6, T8, T11 + S3, S10) } \\
\text { TS5. Effectively use the competitive mindset } \\
\text { programme. (T4, T7 + S3, S10) } \\
\text { TS6. Implement better retention strategies by } \\
\text { offering high rewards and job security. (T8, T11 } \\
+ \text { S2, S3, S10) } \\
\text { TS7. Utilise the legacy network to provide low- } \\
\text { cost services. (T2, T11, T12, T14 + S1, S3, S6, }\end{array}$ & $\begin{array}{l}\text { TW1. Avoid high operating costs per line. } \\
\text { (T5, T9, T14 + W4, W5) } \\
\text { TW2. Avoid establishing network } \\
\text { infrastructure in low population density and } \\
\text { low GDP growth rate countries. (T9, T10, T14 } \\
+ \text { W7, W8, W11) }\end{array}$ \\
\hline
\end{tabular}


S9)

TS8. Negotiate with international operators for partnerships and enter into the market. (T2, T4, T10 + S2, S3, S4, S5, S6, S7, S9)

Table 3: Strategy formulation map

Grand strategies were derived by combining appropriate and relevant strategic options and are aimed at addressing the main strategic issues identified.

\section{Grand Strategies}

The following strategies were identified for Telkom's international business:

International (Africa) market expansion strategy. Expansion of business into the international market can be achieved through the following:

- $\quad$ offering satellite services in those countries that lack terrestrial infrastructure (OS3, OW1).

- $\quad$ aggregating the international calls from other African countries. Telkom will gain more international calls, thereby adding profit and recovering the equipment capital cost (OS1).

- $\quad$ introducing VoIP technology in the international network for bandwidth efficiency (OS6).

- $\quad$ expanding wireless network services (Vodacom) into the high potential market e.g. East Africa (OS4).

- $\quad$ negotiating better deals with the international operators (TS8).

Bandwidth wholesaler for the African continent. Telkom will be able to capture the African market through bandwidth wholesale. This can be achieved through the following:

- utilising the established relationships with the satellite operators for the purchase of additional satellite bandwidth capacity (OS7).

- $\quad$ reselling (wholesale and retail) excess bandwidth capacity available on the terrestrial (SAT2, SAT3/WASC/ SAFE) links (TS2).

- $\quad$ implementing VoIP on the international circuits (OS6, TS1).

Network and infrastructure upgrades for broadband. In order to compete in the global market, it is necessary that Telkom has sound network infrastructure that can cater for all types of future need. To attain this, Telkom must do the following:

- $\quad$ identify the right satellite platform and satellite coverage for the international broadband solutions (OS8).

- $\quad$ implement a highly reliable broadband satellite network that can provide VoIP solutions (OS6, OS8).

\section{Attain cost competitive advantage}

Telkom can attain the cost competitive advantage through the following:

- implementing VoIP on the satellite and terrestrial network, Telkom will be able to provide international voice and data services at competitive rate (OS6, TS1). 
- providing cheaper international rates for South Africa through the aggregation of international calls from other countries diverted through Telkom international network (TS7, TS8, OW10).

- $\quad$ creating tariff imbalance in the international calls.

- $\quad$ creating a price differentiation on a similar service offering of competitors (TS7).

\section{Internal requirements}

To become more competent in the international market, Telkom needs to concentrate on its development in the following areas:

- $\quad$ achieve competence through adequate skills development programmes (OW8, OW9).

- $\quad$ in-house R\&D support (OW2).

- $\quad$ restructure and reorganise the organisation for competitive advantage (OW3, OW4, OW5).

- $\quad$ retain skills through job security, high rewards and better retention strategies (TS6).

\section{Market positioning and entry}

- $\quad$ enter and capture the market at a fast pace.

\section{Tax savings}

- $\quad$ invest in employees through training (OW2, OW6, OW8, OW9).

- $\quad$ initiatives to support the government in crime prevention by offering services on legacy networks (TS7, OW7).

\section{CONCLUSIONS AND RECOMMENDATIONS}

This study was concluded with the development of a set of grand strategies. The main conclusions and recommendations for future research are the following:

- Africa as a whole is still an unsaturated market, with little competition. Mobile technology could be the most appealing or appropriate technology for Africa. Vodacom must take initiatives to expand the mobile network rapidly into other African countries.

- Having identified the advantages of implementing VoIP on the existing infrastructure, Telkom needs to take the initiative to provide value-adding services to the corporate business and telecom operators both in SA and in Africa, on satellite and terrestrial networks using VoIP. To implement VoIP, Telkom requires highly skilled technical personnel that need to get the technical know-how through proper training.

- The success of Telkom's business in the international market will depend on how efficiently the existing legacy networks can be used to support the emerging technologies. It is recommended that wherever possible, Telkom should use the existing networks instead of replacing them with new ones.

- There is a strong need to develop a great teamwork attitude in Telkom. The nature of the current organisational structure is more favourable to creating silos in various sections. To solve this problem, Telkom's senior management should use the competitive mind-set programme to motivate the staff to get accustomed to the new changes that will eventually lead to better teamwork. Due to the current staff volume and their geographical dispersal, this change might not happen overnight.

- It is recommended that for future research, the Delphi technique be used to obtain expert opinion for forecasting. 
- As mentioned among the threats, the Managing the Staff Number Programme, currently running in Telkom, creates much uncertainty among the staff, including the highly qualified and experienced people. It is therefore recommended that clear indications from the senior management about the Managing the Staff Number Programme be passed down to all levels.

\section{REFERENCES}

[1] RADCOM Academy, VoIP, http://www.protocols.com/voip.htm, Visited on 25 October 2002.

[2] Lightfoot, N., Bertoldi, A. \& Heydenrych, A. 2000. South African Internet Services Market (SAISM), BMI-TechKnowledge.

[3] Pearce II, J.A. \& Robinson JR, R.B. 2000. Strategic Management: formulation, implementation, and control. $7^{\text {th }}$ - ed. Singapore: McGraw-Hill.

[4] De Wet, G. 1992. Corporate Strategy and Technology Management: Creating the Interface, CSIR, Pretoria.

[5] Lindsay, J. 2000. Technology Management Audit A Company Self-Assessment Tool. Cambridge: Pearson Education Limited.

[6] Nieto, M., Lopez, F. \& Cruz, F. 1998. Performance analysis of technology using the S curve model: the case of digital signal processing (DSP) technologies. Technovation, vol.18, no.6/7, p.439 - 457 . 